\title{
A Comparative Study of Foreign Investment Laws in Ghana and South Africa:
}

\author{
-A Review \\ Dorothy Mamphey - Otibo \\ Koforidua Technical University, Ghana. Department of Liberal Studies \\ dorothy.mamphey-otibo@ktu.edu.gh
}

\begin{abstract}
Over the last decade, Ghana and South Africa have been among some African countries that have become more entrenched in foreign direct investment (FDI). The past quarter of the century has witnessed a remarkable growth in world foreign direct investment flows, coupled with the evolving investment strategies of national policies globally. This paper examines and compares the legislative frameworks and regulatory policies governing FDIs in South Africa and Ghana and the hurdles that need to be overcome to ensure smooth implementation of these policies. This has become evident in their current enactment of their regulations with the object of promoting investments in these economies. However, these jurisdictions have restrictions placed on their regulations; hence, putting frustrations on foreign direct investments. It appears that although in terms of overall statutory FDI regulations, African countries are on the average not more restrictive than other developing nations, some of these countries have obstacles that are both severe and restrictive such as land ownership, whether discriminatory or general in nature, act as an important deterrent to foreign investment. This discussion would focus on comparing restrictions imposed by legislation or policies affecting Soith Africa anf Ghana with regards to foreign direct investment. And disputes that emerge due to the restrictions among the jurisdictions.
\end{abstract}

Keywords: Foreign Direct Investment, Economic Growth, International Law, Legislative Framework, Regulatory Bodies, Bilateral Investment Treaties.

\section{Introduction}

The United Nations Commission on International Trade Law (UNICITRAL) in 1968, held its session to among other things discuss and consider the removal of legal obstacles to international trade by progressively modernizing and harmonizing trade law. Its mandate covered the preparation of legal texts in a number of key areas such as international commercial dispute settlement among others. During the Second Session of the UNICITRAL in 1969, the representatives of Ghana and India suggested that the then Asian-African Legal Consultative Committee (AALCC) should revive its consideration of the subject on the International Sale of Goods so as to reflect the AsianAfrican viewpoint and the request was considered as a priority at the Eleventh Session held in Accra in 1970. Other policies by UNICITRAL such as UNICITRAL Arbitration Rules ( have since been adopted since 2010. Developed, developing and under developed countries have in recent times accelerated their policies and regulations on foreign direct investment regarding international laws. The object of international investment is to contribute to economic growth in jurisdictions that are developing or under developed. (Abudulai, 2004) submited that the policies of these countries have been formulated to promote FDI, although certain restrictions imposed have however hindered the smooth dissemination of these policies hence achieving little on the objects of these policy frameworks. In Ghana, there has been a much more liberalised regime for FDI, addressing investors' concern, privatising public enterprises and actively promoting investment, all of which 
are aimed at creating a good environment to boost investor confidence.

According An international agreement is a type of treaty between states that addresses issues relevant to crossinvestments usually for the purpose of protection; promotion and liberalization of such International Investments Agreements (IIAs). UNICITRAL reports that jurisdictions concluding IIAs have commited themselves to adhere to specific standards on treatment of foreign investments within their territories and IIAs have defined procedures for the resolution of disputes should these commitments not be met The most common types of IIAs include Bilateral Investment Treaties (BITs). South Africa concluded its BIT with Ghana in 1998 and reviewed its BIT policy from 2008 to 2011. Additionally, Ghana has signed and ratified a convention on Double Taxation Agreements with South Africa with a view of avoidance of double taxation and the prevention of fiscal evasion with respect to taxes on income and capital gains on 2nd November, 2004. Bilateral trade volumes between Ghana and South Africa recorded an upward trend from R2.6 billion to R10.8 billion between 2010-2014 (Business News, 2015). Ghana is a member state to the International Centre for Settlement of Investment Disputes (ICSID) convention and a signatory to the convention on the Recognition and Enforcement of Foreign Arbitral Awards (1958 New York Convention).

\section{Methodology}

This comparative study has benefited from a wide range of date from different sources that include legislation, international and regional investments instruments, official instruments and judicial decisions of relevant bodies such as Investment Centre for Settlement of Investment Disputes (ICSID) Investor State Dispute Settlement (ISDS) and others thereby articulating a detailed analysis of a phenomenon. . Other sources included policies and reports by various international treaty bodies such as Organization for Economic Cooperation and Development (OECD), United Nations Commission on International Trade Law (UNICITRAL) International Monetary Fund (IMF), World Trade Organization (WTO) and regional treaty bodies such as Trade and Investment South Africa.

The comparative perspective enabled this study assess the success or otherwise of the different approaches to Foreign Direct Investments (FDIs) in South Africa and Ghana thereby eliciting a wider understanding of promoting, protecting and sustaining FDIs in Africa as a whole. In theoretical terms, the comparative examination of foreign investment laws enhances explanatory power and adds to the theoretical value of a study by allowing researchers to examine in a broader context the protection and promotion of a particular phenomenon.

Thus, the study did not limit itself to the developments in the two countries but it also appraised events occurring internationally such as FDIs in the European Union (EU). In that regard, the developments in International Investment Agreements (IIAs) and Bilateral Investment Treaties (BITs) in South Africa and Ghana in recent times have emerged as mechanisms aimed at protecting and sustaining FDIs

\subsection{The Concept Of Foreign Investment}

In the case of State Enterprise "Energorynok" (Ukraine) v The Republic of Moldova SCC Arbitration V 2012/175, the concept of "investment" under the applicable IIA and the ICSID was said to qualify as an agreement between Moldova and Ukraine concerning the supply of electricity into Moldova which suggested an existence of investment for the purpose of Energy Charter Treaty (ECT), however, the tribunal found Energorynok's claim to money under that agreement not qualified as an investment, reasoning that, under Article 1(6)(c) of the ECT, a claim to money must be associated with some other self-standing investment in the energy-related economic activity out of which the claim to money arose. (Borensztein et al, 1998) further posits that, FDI is an important vehicle for the transfer of technology, contributing relatively more to economic growth than domestic investment when a sufficient absorptive capability of advanced technologies is available in the host country. Further, (Mahembe, \& Odhiambo, 2013) explain that FDI, according to both theoretical and empirical literature, is defined as an international investment by an entity resident in one economy in the business of an enterprise resident in another economy that is made with the objective of obtaining a lasting interest that can contribute to economic growth (Ajayi, 2006). submits that FDI is one of the most dynamic international resource flows to developing countries, packaged as tangible and intangible assets that play important roles in the global economies, and can affect economic growth by complementing domestic investment and by facilitating trade and transfer of knowledge and technology. (Ajayi, 2006) explains that it suffices to say that FDI is an important source of capital as it complements domestic investment, creates new job opportunities and relates to the enhancement of technology transfer hence, boosting economic growth and minimizing poverty in a particular environment. (Abudulai, 2004) argues that although FDI is expensive, it is also risky in the sense that a 
firm must establish production facilities in a foreign country or acquire a foreign establishment; it is also risky in the sense that because of the challenges associated with doing business in a different country, the rules of the game might be very different ( Ajayi, 2006) submits that FDI can be categorized into three types: the first is market-seeking FDI or horizontal FDI whose purpose is to serve local and regional markets; the second type is resource-or asset seeking or vertical FDI with its target on resources which may be natural resources, raw materials for manufacturing sector when multinationals directly invest in order to export; and the third type known as efficient-seeking FDI which targets the common governance of geographically dispersed activities in the presence of scale and scope. (Mahembe, \& Odihambo, 2013) have argued that FDI represents a potential source for sustainable growth and development given its assumed ability to generate technology spillovers, assist in human capital formation and development, help the host countries to integrate into the global economy trade, assist in the creation of a more competitive business environment, and fill the funding gap between local savings and investment requirements that augment the host country's balance-of-payment receipts.

\subsection{Comparison of the Concept of Foreign Investment in} South Africa and Ghana

In their statutory dispensations, South Africa and Ghana have, as a matter of importance, enacted regulations to regularize their FDIs (GIPC ACT 2013 \& PI ACT 2015). South Africa had their statute emanating from the termination of certain BITs and the introduction of Promotion and Protection of Investment Act 22 of 2015 (PPIA) to promote and protect investments so as to limit the role of IIAs in protecting FDI. South Africa's policy framework on FDIs appears to justify a policy shift that guarantees and mitigates the risk to foreign investors' mandatory need to reclaim policy space from BIT practice, the unpredictability of interpreting BIT provisions, the ambivalent empirical evidence on the importance of IIAs in attracting FDIs and the importance of developing local institutions. Section 4 of the Promotion and Protection of Investment Act 22 of 2015 stipulates that its purpose is to protect investment in accordance with and subject to the Constitution of South Africa, in a manner which balances the public interest and the rights and obligations of investors; affirm South Africa's sovereign right to regulate investment in the public interest; and confirm the Bill of Rights in the Constitution and the laws that apply to all investors and their investments. (Sharp, 2015) suggests that the decentralized Investment Promotion Agency (IPA) system may sometimes create extra hurdles for foreign investors who already have to navigate a complex system to get their business started as they need to apply for general business licenses at the Department of Trade and Industry, obtain visas for their foreign personnel at Department of Home Affairs, complete business and tax registration at the South African Chamber of Commerce and complete additional bulky paperwork for land and utilities. Section 4 of the GIPC ACT 2013, on the other hand, regarding Ghana, stipulates that "the functions of the Ghana Investment Promotion Centre shall for the purposes of attaining its object; actively encourage, promote, and facilitate investment promotion policies and plans, promotional incentives and marketing strategies to attract both foreign and local investments in an advanced industries and skill-intensive services which would enjoy good export market prospects; initiate and support measures that will enhance the investment climate in Ghana for both Ghanaian and non-Ghanaian enterprises." (Abdulai, 2004) has posited that in Ghana, there has been a much more liberated regime for FDI, addressing investors' concern, privatising public enterprises and actively promoting investment all of which are aimed at creating a good environment to boost investor confidence; thus, expansion of the scope of FDI has taken place to reduce the number of industries closed to foreign investors. Further, the GIPC ACT 2013 seeks to initiate, organize and participate in promotional activities such as exhibitions, conferences and seminars for the stimulation of investments to present and project Ghana as an ideal investment destination; collect, collate, analyse and disseminate information about investment opportunities and sources of investment capital, incentives available to investors, the investment climate and advise upon request on the availability, choice or sustainability of partners in joint venture projects and register, monitor and keep records of all enterprises in Ghana.

\subsection{The Right of Establishment}

\subsubsection{Entry Condition}

New Parnership for Africa's Development and Organisation for Economic Coporation Development Investment Initiative (NEPAD/OECD Investment Initiative 2005) instituted a roadmap since the early 1990s, with most African countries including Ghana and South Africa generally simplifying their procedures for entry of FDIs, with little or no screening on entry but with the transparency in registration and just meeting the proper criteria; however, 
some countries impose general restrictions on entry, either by prohibiting foreign investment below a certain size, through minimal capital investment or by requesting prior approval or licensing from which domestic investors are exempted. It is interesting to note that Ghana, among other African countries, has relaxed restrictions on foreign purchase of domestic shares in capital market, thus accepting the obligations of Article VIII of the International Monetary Fund's Article of Agreement which compels countries to remove restrictions on payments and transfer for international current transactions and to adopt multilateral payment system free of restrictions and discriminations as motivated by NEPAD/OECD Investment Initiative. South Africa and Ghana are among African countries which impose requirements on entry of FDI both on general and specific restrictions on entry, according to NEPAD/OECD Investment Initiativ,e with South Africa employing liquidation proceeds transfer abroad in cases where a South African company is fully owned by non-residents.

Further, through NEPAD/OECD Investment Initiative,South Africa has put measures that can contribute to the relaxation of their laws on FDIs by reducing import tariffs and subsidies to local industries, eliminating the discriminatory non-resident shareholders tax, removing certain limits on hard currency repatriation, halving the secondary tax on corporate dividends, lowering the corporate tax rate on earning and permitting foreign investors hundred percent ownership while Ghana on the other hand, allows foreign investments on foreign purchase of shares with foreign ownership not exceeding seventy-four percent, individual's holdings and combined holdings by non-residents in any one of securities listed on the Ghana Stock Exchange not exceeding ten percent in relation to individuals and institutional investors. GPIC Act stipute that On transfer of profits and the proceeds of liquidation, the law is clear as to foreign investors guarantee on the right to repatriate through any authorized dealer bank in convertible currency, dividends, net profits, interest payments, remittance of proceeds, as well as transfer of payments in respect of loan servicing where a foreign loan has been obtained, fees and charges in respect of technology transfer agreements registered under the law.

\subsection{Capital Requirements}

Financially, Ghana has a pre-condition requirement for FDIs as stipulated in the GPIC ACT. As a requirement, a foreign investor is expected to satisfy a minimum capital of US $\$ 10,000$ (for joint venture with a Ghanaian) or US\$ 50.000 (for enterprises wholly-owned by a non-Ghanaian).
In terms of section 28 (1) (a) (b) of the GPIC ACT, the minimum capital required by trading companies either wholly or partly owned by non-Ghanaians is US\$300.000 and under obligation to employ at least ten (10) skilled Ghanaians. Further, a person who is not a citizen may participate in an enterprise with a minimum capital of not less than US $\$ 200.000$ in cash or capital goods relevant to the investment or a combination of both by way of equity participation and the partner who is a citizen, does not have less ten percent equity participation in the joint enterprise or where the enterprise is wholly owned by that person, invests a foreign capital of not less than $\$$ US500.000 in cash or capital goods relevant to the investment or a combination of both, employ twenty (20) skilled Ghanaians.

The exception to this rule is that, the minimum foreign capital required is not applicable to the foreign spouse of a citizen of Ghana, if the foreign spouse of a citizen has been married to a citizen for a minimum period of five years continuously or holds an indefinite resident permit prior to registration of an enterprise with the marriage duly verified as valid. The GIPC law further stipulates that the minimum capital requirement does not apply to portfolio investments or an enterprise set up solely for export trading and manufacturing.

\subsection{Restricted Activities}

Section 27 of the GPIC Act stipulates that a person who is not a citizen or an enterprise which is not wholly owned by a citizen is prevented by law to invest or participate in the sale of goods or in the provision of services in a market, petty trading or hawking or selling of goods in a stall at any place; the operation of transport services of a fleet of less than twenty five vehicles; the production, supply and retail of sachet water; the production of basic stationery and the retail of finished pharmaceutical products. The GIPC law applies to foreign investment through acquisitions, mergers, takeovers, portfolio investments in stocks, bonds, and other securities traded on the Ghana Stock Exchange. Further, the GIPC law governs investments in all sectors of the economy except minerals and mining, oil and gas, and the free zones, although sector-specific laws regulate those sectors such as banking, non-banking financial institutions, insurance, fishing, securities and real estate.

Small scale mining in Ghana is reserved for citizens and investments in the mining and minerals sector is regulated by the Mining and Minerals Law 1986 (PNDCL 153) as amended by the Minerals and Mining Amended Act 1994 with the Minerals Commission administering the Mining and 
Minerals Law such as mining rights and ownership. The Petroleum Exploration and Production Law 1984 (PNDCL 84) deals with issues regarding oil and gas in Ghana and is overseen by the Ghana National Petroleum Corporation (GNPC). It has been submitted that major foreign investments in Ghana are mainly in mining and manufacturing sectors, with Britain as Ghana's main foreign investor which has a direct investment exceeding USD $\$ 750$ million, followed by India. It must be emphasized that mining companies have expressed concerns about problems that have adverse effect on their operations such as bureaucratic delays in dealing with the Bank of Ghana as well as a number of tax issues; further, other emerging mining economies such as Zimbabwe, Mali and Tanzania as competitors have resulted to the loss of attractiveness of Ghana as a destination for mining investments(Ajayi,2006).

In South Africa, the Competition Commission, under the auspices of Competition Act of 1998, is empowered to investigate, control and evaluate restrictive business practices, abuse of dominant position and mergers in order to achieve equity and efficiency. South African Competition Law allows the commission to review investment for public interest considerations such as its effect on specific industrial sectors, employment within South Africa, the ability of national industries to compete internationally. However, these broad powers present a risk; which is political interference that imposes requirements that discriminate against foreign investors. Virtually, all business sectors are open to foreign investment; however, certain sectors such as energy, mining, banking, insurance and defence require government's approval with the Department of Trade (DTI) and Trade and Investment South Africa (TISA) providing assistance where necessary. TISA offers information on sectors and industries, consultations on the regulatory environment, facilitation for investment missions, links to joint venture partners, information on incentive packages, assistance with work permits and logistical support for relocation. DTI concentrates on sectors in which research indicates the foreign country has a comparative advantage

\subsubsection{Expansion of Investment}

Accprding to United Nations Polices and Bilateral Investments Treateis in Africa (2016) investments in Africa particularly, South Africa and Ghana has surged in recent years, largely due to its growth performance in the last decade, its rising consumer markets, the high rates of return on investments as well as natural resources wealth, although prospects of increases in foreign investments have improved, perceptions about these countries reign deeply among some foreign investors. According to a suyvey conducted by the Department of Tarade and Industry (DTI) in South Africa in 2012 and documented in a Cordinated Direct Investment Survey, Ghana by way of expansion, has twenty-one BITs with other countries while South Africa has forty-six BITs with other countries, thus enabling its expansion of foreign investments. Generally, Ghana does not have performance requirements for establishing, maintaining and expanding a business, with investors not required to export a specified percentage of their output except for Free Zone enterprises which in accordance with the Free Zone Act 1995 (Act 504), must export 70\% of their products. South Africa, on the other hand, uses government procurement policies to promote and expand domestic economic development and fight employment and its legal framework of Preferential Procurement Policy Act No. 5 of 2000 has been enacted to commit the government to boost industrialization and to create jobs thereby increasing the proportion of goods and services procured from South African suppliers to an "aspirational target" of $75 \%$.

\subsection{Payment Of Taxes}

FDIs are required by law to register their companies with the South African Revenue Service (SARS) in terms of SARS requirements in order to get an income tax reference number for turnover tax (small companies), corporate tax and as well as employer contribution for PAYE (income tax) and skills development levy (applicable to most companies). The smallest informal companies may not be required to register with Companies and Intellectual Property Commission (CIPC), but they must register with the tax authorities. The principal source of indirect taxation revenue in South Africa is Value Added Tax with Foreign tax credits that grant rebates in equal to the sum of any taxes on income payable to the government of another country. Other taxes that affect foreign owned companies are Donation Tax, Customs and Excise Tax Act 1964, Tax Administration Act 2011. Ghana's framework on taxes, on the other hand, are Internal Revenue Act 2000 (Act 592) as amended, Internal Revenue Regulation 2001 (L1 1675) and Value Added Tax Act 1998 (Act 546) and Customs, Excise and Preventive Service (Management) Law 2003 Act (PNDC 330) as amended and these legislations define the extent of application on FDIs.

\subsection{Tax and Duty Incentives}

According to KMPG Africa Incentive Survey in 2016, Ghana and South Africa among other countries in Africa, 
offer a range of enhanced tax incentives, ranging from accelerated allowances for capital expenditure, special allowances for investments in certain industry sectors (such as manufacturing, infrastructure, tourism) as well as tax holidays ranging from three (3) to ten (10) years. South Africa offers a dedicated $R \& D$ tax incentive regime with an enhanced tax deduction (150\%), equivalent to that offered by OECD countries.

The KMPG Africa Incentive Survey further through their findings identified the South African government, through the DTI, Department of Science and Technology (DST) and SARS availed to the business community, tax incentives in the field of infrastructure development, the manufacturing sector and research and development projects (R\&D). While DTI administers the manufacturing and development incentives as well as provides grant funding to applicants, DST and SARS manage the R\&D tax incentive so as to increase private sector investment. It should be noted that both the manufacturing of vehicles and its components in the Automotive Industry are fully supported with a range of cash grants and rebates by the South African government. The benefits are categorized as R\&D Tax incentive, Employment Tax incentive, Greenfield and Brownfield Expansion projects, Energy Efficiency Tax Deduction, and Special Economic Zones. In addition to tax incentives, foreign investors in South Africa can benefit from the Foreign Investment Grant which aims at assisting foreign companies to relocate machinery and equipment from overseas to South Africa and the scheme is available to foreign investors with a shareholding of at least fifty percentGhana has introduced various tax incentives to stimulate investments and through its legislation, the Income Tax Act (896) 2015, GIPC and the Ghana Revenue Authority availed specific incentives depending on the nature of business and investments. The incentives are categorized into Tax incentives available to companies in specific industries for specified number of years, incentives available to companies engaged in agro-processing and cocoa by-products, Ghana Free Zones (industrial zones/freeports) and general investment incentives upon registration with GIPC. It is interesting to note that such incentives must be approved by parliament through the sector ministry.

2.8 Host Country's Legislation on Foreign Investment

\subsubsection{Labour Law}

South Africa Investment Hnadbook (2014/2015) explainds that South African labour employment relations is regularized by common law, employment contract or letter of employment, employment policies and procedures, collective agreements concluded with trade unions and organized labour, sectorial determinations and bargaining council agreements that regulate basic conditions of employment in a specific industry and legislation. Labour legislation in South Africa requires companies to register their companies with the Department of Labour to contribute to the Unemployment Insurance Fund (UIF) and a compensation fund for occupational injuries. The Labour Relations Act No. 66 of 1995 (LRA), aims at promoting economic development, social justice, labour peace and democracy in the workplace. LRA applies to all employees, workers, trade unions and employers' organizations. It must be emphasized that the primary objective of the LRA is to realize and regulate the fundamental rights of workers as entrenched in the Constitution. The purpose of Employment Equity Act No. 55 of 1998 (EEA) is to promote equal opportunities and fair treatment to all in the workplace by eliminating unfair discrimination; and to implement affirmative action measures to redress the disadvantages in the employment experienced in the past by members from designated groups, in order to ensure their equitable representation in all occupational categories of employment. Further, section 6(1) of EEA stipulates that there should be equal pay for equal work; implying that employees of the same employer, performing the same work or work of equal value, must not be treated differently in terms of benefits, and remuneration, unless justifiable reasons exist for the differentiation. It should be noted that where the employee is treated unfairly with regards to benefits and remuneration or any other arbitrary grounds without justification amounts to unfair discrimination against the employer. The Basic Condition of Employment Act No. 75 of 1997 as Amended by Basic Conditions of Employment Amended Act, No 11 of 2002 (BCEA) gives effect to the constitutional right to fair labour practices by enforcing basic minimum conditions of employment such as working hours, leave durations, particulars of employment and remuneration as well as notice of termination of appointments.

The Occupational Health and Safety Act No. 85 of 1993 (OHSA) requires an employer to provide a safe working environment without risk to the health and safety of its workers, rights and responsibilities of employees and employers respectively regarding health and safety, a working environment free of hazardous substances and awareness on the prevention of workplace injuries and accidents. However, in terms of the OHSA, the employer is 
not expected to take the sole responsibility for health and safety at the work place; there must be collaboration between the employer and employee on safety measures at the workplace by sharing the responsibilities of safety measures to prevent and minimize risk. The Act further empowers both employer and employee to be partners in the safety measures, by forming a committee that monitors health and safety measures at the work place.

It is worthy to note that section 14 (a)-(e) of the Labour Act, 2003 (Act 651) prohibits restrictive conditions of employment by requiring an employee to join or form a trade union of his choice; requires that an employee participate or refrain from participating in the lawful activities of a trade union; a refusal to employ a person because that person is a member of a trade union; promise the person any benefit or advantage for not participating in trade union activities. Further an employee should not be discriminated against on grounds of gender, race, colour, ethnic origin, religion, creed, social or economic status, disability or politics.

\subsection{Environmental Laws}

The Bill of Rights entrenched in the South African Constitution explains the right to an environment that is not harmful to one's health, thus making it incumbent on the South African government to take reasonable legislatives such as South African National Environment ActEnvironmental Laws Amended -No 14 of 2009 (NEMA), The National Water Act No.36 of 1998(NWA), The National Environment Management Waste Act No. 59 of 2008(NEMWA) and other measures to ensure that this environmental right is attained and protected. Furthermore, The National Environmental Management-Air Quality Act No. 39 of 2004 (NEMAQA) has been enacted to protect and enhance air quality throughout South Africa, administer a more stringent air quality control in comparison to the previous Atmospheric Pollution Prevention Act No.60 of 1965, as well as prevent air pollution and ecological degradation and secure ecologically sustainable development. Ghana, on the other hand has its environmental laws embodied in Environmental Protection Agency Act, 490, 1994 which seeks to regulate the environment and ensure the implementation of government policies on the environment.Adjarko H.,Gemadzie J., Agyekum K., (2016)suggest that the Act mandates the Environmental Agency to ad infinitum improve and preserve the country's environment as well as seek solutions to global environmental issues although there is little knowledge of this law.

\subsection{Comparison of Investment Guarantee}

\subsubsection{National Treatment}

The Protection of Investment law promotes a fair treatment of foreign investors and South Africans in circumstances which imply an overall examination which must not be limited to or be biased towards one factor of the merits of the case but by taking into account all the terms including the effect of the foreign investment in the country and the cumulative effects of all investments, as well as sectors that the foreign investments are in, aim of any measure relating to foreign investments; factors regarding the foreign investor or the foreign investment relating to the measures concerned, effect on employment, environment and direct and indirect effect on the environment. Adjarko H.,Gemadzie J., Agyekum K., (2016) argue that while South African government supports investment in principle, investors and market communicators are concerned that its commitment to assist foreign investment is insufficient in practice based on the belief that the national-level government lacks a sense of urgency when it comes to supporting foreign investment deals.

Additionally, South Africa scrutinizes merger-and acquisition-related foreign direct investment for its impact on jobs, local industry and retaining South African ownership of key sectors. Despite South African general openness to investment, actions by some government ministries and statements by politicians provide troubling examples of a lack of potential impact domestic policies on investments as well as policies such as Broad -Based Black Economic Empowerment (B-BBEE) programme which is an affirmative action implemented to deal with the historically disadvantaged citizens to participate in the economy.Adjarko H.,Gemadzie J., Agyekum K., (2016) It should be noted that B-BBEE provides equity equivalence deals that allow multinational corporations on ownership dimension without the transfer of equity stakes that is likely to be involved in the creation of black-owned joined venture valued at least $25 \%$ of the multinational's South Africa operations.Adjarko H.,Gemadzie J., Agyekum K., (2016).

\subsubsection{Most-Favored-Nations (MFN) Clause}


Kanyangoga,J.B.(2014) explains that the Most Favored Nation (MFN) clause is a principle of non-discrimination of any concession or privilege granted by one contracting to General Agreement on Tariffs and Trade (GATT) to a product of another contracting party to GATT to a product of another contracting party which will be unconditionally granted to the like product of all other contracting parties. Further, MFN principle is about treating others equally as emphasized under World Trade Organization agreements which expressly indicate that countries cannot discriminate between their trading partners. Bronfman, M.K. (2006) has posited that MFN is another standard of protection that grants the foreign investor a safety net for his investment as well as a dispute settlement system that allows for any of the parties or their national investors to have access to the United Nations Commission on International Trade Law (UNCITRAL) or ICSID.

\subsubsection{Interpretation of the main clause of $\mathrm{MFN}$}

Ayangbah S.,Sun L \& Martyn J., (2017) argues on the essence of MFN treatment as ensuring a level playing ground among all trading partners and is therefore the central of the international trading system. Additionally parties are to include an MFN clause in their agreements to ensure that each will be able to benefit from better terms entered into with third parties. It must be emphasized that exceptions to the MFN principle are however allowed under WTO. For example developed countries can give developing countries such as South Africa and Ghana special access to their markets under the special "enabling clause" adopted by W'TO in 1979. Ghana offers commitments at the bilateral level to protect investors and their investments. Ayangbah S.,Sun L \& Martyn J., (2017) further explains that under these bilateral regimes, government gives the right to the investor to take government to arbitration in any of the selected and pre-agreed dispute settlement fora. Further protection under the BITs include national treatment, which is by reference to the standard of treatment not less favourable than that accorded to nationals and investors of third world countries in similar circumstances, and treatment which is fair and equitable and derived from basicprinciples of international law and a common shared sense of justice. Similarly, South Africa applies MFN rates of imports from the rest of the world, as well as preferential rates applied to products originating from trade partners with which it has negotiated trade agreements.

2.12 Fair and Equitable Treatment- Fet (South AfricaGhana)
Bronfman, M.K. (2006) subnmitted that the fair and equitable treatment (FET) principle provides elements available to a foreign investor to protect his investment in a foreign country, because it provides him with certain treatment that the host state must grant regardless of the treatment given to its own nationals. It must be emphasized though that while the standard is applied by arbitrators with most investment agreements granting this principle/standard, they do not provide an indication as to what its exact meaning is and what the criterion is by which it must be applied. (Bronfman,M.K.(2006).He further argues that developed countries have become concerned about the real effect FET will have on their nationals who invest in capital-importing countries for the reason that FET has been given many interpretations in arbitral cases thus instead of promoting stability and certainty among investors, the situation rather produces exactly the opposite effect. It should be noted however that, developing countries such as Ghana and South Africa's acceptance of FET will promote fundamental moral and legal grounds of the notion of fairness, anchored in a universally accepted sense of justice and classic customary rules governing the protection of foreign nationals and companies.

According to Schlemmer C.E. (2016), South Africa BITs are found to be fairly standard when it comes to their content, other than what one could have expected of a state that was in a process of transformation when these treaties were signed and thus in a perfect situation to take its own domestic needs and policies into account. However, this was not done due to the sudden awareness of the fact that BITs perhaps could entail more harm than good when South Africa became involved in investment arbitrations as a result of some of its internal policies and legislations leading to complaints of treaty violations. Schlemmer, C.E.(2016) further posited that as a result of this, a review of the government's investment policy framework has been taken and a number of its BITs terminated and replaced with a new domestic framework for the protection of foreign investment, doing away with investor - state arbitration.According to Dolzer,R.(2014), the standard of fair and equitable treatment principle had become the prominent standard in investment treaties and has remained steady and intensified. More over, this has become possible due to BITs setting forth limited number of substantive absolute standards in situations when the facts of the dispute do not clearly support the claim for direct expropriation, but when there are notwithstanding events that need to be assessed under a different standard to provide redress in the event that the rights of the investor have been breached. 


\subsection{Transfer of Funds/Capital}

Ghana and South Africa among other developing countries, with the view to encouraging FDIs, have put in place policies to promote FDIs and permits transfer of profits. Section 27 of GIPC Act stipulates that foreign investors are guaranteed the right to repatriate (through any authorized dealer bank in convertible currency) dividends, net profits, interest payments, remittance of proceeds as well as transfer of payments in respect of loan servicing where a foreign loan has been obtained, fees and charges in respect of technology transfer agreements registered under the GIPC law; whereas capital invested in South Africa, as well as interests and profits can be freely repatriated. It should be noted however that if a South African company is fully owned by nonresidents, there are certain requirements that need to be satisfied before transfer of profits abroad can be authorized. In situations where the ownership has a South African partner, the non - resident can transfer profits without restrictions.

\subsection{Investor-State Dispute Settlement (South Africa- Ghana)}

Freehills,S.H.(2016) submits that most disputes in Africa are solved through commercial settlement with companies and states alike preferring negotiation over the uncertainties of litigation or arbitration, however, the emergence of foreign investment globally has brought about internationally arbitral rules. An Investor-State Dispute Settlement (ISDS) mechanism allows a state to assume obligations that may be detrimental in the long run as with capital importers, developing countries bear most of the risk of investor litigation inherent in signing an IIA, further IIA obligations can lead to a loss of national policy space for host states by creating legal obstacles that restricts its ability to change key regulation, Freehills,S.H (2016) has posited that ISDS has been designed for depoliticizing investment disputes, and creating a forum that would offer investors a fair hearing before independent, neutral and qualified tribunal. According to Freehills,S.H.(2016), discussions of ISDS by governments such as South Africa and Ghana have permitted Freedom of Investment (FOI) to assist in mapping and exchange of views about the diverse policies and practices in international law. Whereas Ghana under Washington Convention on the Settlement of Investment Disputes Between States and Nationals of Other States (the Convention)( ICSID) has signed BIT with South Africa as at 22nd July 2016, South Africa is yet to sign and ratify with Ghana. It is worth noting that Ghana's Arbitration Act,
Alternative Dispute Resolution Act 2010, Act 798, has been provided for the settlement of disputes by arbitration, mediation and customary arbitration and to establish an Alternative Dispute Resolution Centre, whereas the principal legislation which applies to arbitrations in South Africa is the Arbitration Act 42 of 1965 which applies to international and domestic arbitration proceedings conducted in the country to promote fair and efficient arbitrations. In Piero Foresti,Laura de Carli \& Others v The Republic of South Africa ,ICSID Case No. ARB (AF)/07/01, the government in South Africa, shortly after settling a dispute with a mining company over its new post-apartheid mining laws, began withdrawing from BITs that include ISDS arguing that they belong to a bygone era. The defendant further claimed that BITs focus on the interests of investors from developed states and do not address the concerns of developing state. Xavier,C.(2016) explains that the South African government decided to develop a new model BIT and strengthen its domestic legislation in regard to the protection offered to FDIs. Further, South Africa sought to incorporate legitimate exceptions to investor protection where it warrants public interest considerations.Further, Xavier , C. (2016) submits that South Africa's BITs with other African countries are still in place, it finds itself in a situation where investors who come from countries that have BITs with South Africa can opt for international arbitration instead of domestic dispute settlement, leaving the country exposed to too many simultaneous platforms of dispute settlement.

\section{Conclusion}

The fDI Report (2016) Global Greenfield Investments Trends submits that South Africa and Ghana are middleincome and developing countries racing towards the rapid globalization of FDIs. Key trends in 2015 for instance, indicates that FDIs into Africa in terms of project numbers increased by $6 \%$, with South Africa being the top Africa destination for inward FDI continuing a long-term trend capital investment of 2.5 billion\$.FDIs will always be part of developing and developed countries; however, jurisdictions must aim at addressing some challenges of IIAs. It is worth noting that South Africa has opened its Draft Regulations on Mediation Rules for public comment until February 2017. It appears the worldwide legal framework for protecting investments from unjustified governments action is fragmented, hence, lowering FDIs confidence. Jurisdictions have the right to regulate this and this seems a consequence of state sovereignty and in exercising such rights, they must not breach their international obligations although they must protect the environment, regulate the quality of work, and 
supervise the work generally. South Africa and Ghana have been able to put adequate regulations in place to facilitate FDIs; however, these two jurisdictions need to attract investments from the developed nations such as China and America although comparatively South Africa is a more developed economy than Ghana.

UNICITRAL Rules on Transparency in Treaty-Based Arbotration which has been implemented since $1^{\text {st }}$ April 2014 states that current trends in ISDS indicate that proceedings that are known to have been concluded, just a third of the cases decided are in favour of the State with the others granting monetary compensation to investors. Further, UNICITAD Reform of Investor - State Dispute Settlement Policy 2012 clearly indicates the need to pay attention to Arbitration Rules that have been stipulated by UNICITRAL to minimize states treatment of investors. UNICITAD,Reform of Investor-State Dispute Settlement Roadmap explains that IIA reforms are intensifying and yielding results regarding investment dispute settlement and the substantive content of IIAs which are preserving the rights and protection of investors and also improve investment dispute settlement through legislatives and treaties.

Ewelukwa,U.(2014) submits that Ghana can learn some important lessons from South Africa and develop a comprehensive legislation on FDI. Ghana, must first of all, review its BITs in the past, work out a comprehensive assessment of its participation in the ISDS system and experience and finally, open a public discussion about the country's BIT policies and international investment laws.

\section{References}

Ghana Investment Climate Statement 2015, Available at http://www.state.gov./IMF http:unctad.org/en/Docs/iteipcmisc14rev_en.pdf. pg.12 Coordinated Direct Investment Survey 2012.http://www.export.gov.ghana (10/04/2017).

Investments Policies and Bilateral Investments Treaties in Africa: Implications for Regional Integration. United Nations Economic Commission for Africa, available at www.uneca.org (2016)

KPMG "Africa Incentive Survey 2016. Africa is open for Business" A guide to Tax Incentives in Africa." March 2016. Available at http/ /:www.kpmg.com/Africa/en/kpmg-inafrica/pages/2015-african country-reports.

NEPAD/OECD "Investment for African Development: Making it Happen" a NEPAD/OECD Investment Initiative, (2005)

South Africa-Foreign Investment-Attitude Toward FDIs , South Africa -Openness to and Restriction on FDIs- Available at bttp:/ / export.gov/ usoffices.(08/11/2016)

Southern African Development Community Model Bilateral Investment Treaty (July 2012).

The fDI Report 2016 Global Greenfield Investment Trends. Pg 14.Available at fDiMarkets.com.www.fDiIntelligence.com (06/04/2017).

UNICITAD, Reform of Investor -State Dispute Settlement: in Search of a Roadmap. IIA Issue Note No.2 June

2012),http://www.unctad.org/en/PublicationsLibr ary/webdiaepcb2013d4_en.pdf.

UNICITRAL 'Report on the Work of United Nations Commission on International Trade Law (UNICITRAL) and other International Trade Law' Asian - African Legal Consultative Organization (AALCO)/54/BEIJING/2015/SD/S12.

Abdulai, I. (2004). "Sectorial Analysis of Foreign Direct Investment in Ghana" WP/BOG-2005/15 pp1-16.

Adekoya F. (2015) “An Appraisal of the Legal Framework for the Protection of Foreign Investment in Nigeria" Africa International Legal Awareness, Ministry of Justice, Nigeria, 2015.

Adeleke, F. (2015) “Benchmarking South Africa's Foreign Direct Investment Policy" Economic Diplomacy Programme, April 2015. South African Institute of International Affairs, p5-6.

Adjarko H., Gemadzie J. \& Agyekum K. (2016) "Construction Related Environmental Laws and Policies in Ghana: ALiterature Review" Asian Journal of Science and Technology Vol. 07, Issue 05, pg 2984-2992. 
Ajayi, S.I. (2006). "Foreign Direct Investment in SubSaharan African: Origins, Targets, Impact and Potential" African Economic Research Consortium (AERC). p1.

Ayangbah S.,Sun L \& Martyn J., (2017) “Comparative Study of Foreign Investment Laws:The Case of China and Ghana" Cogent Social Services Vo.1 3 Iss.1, p12.

Borensztein et al (1998) "How does foreign investment affect economic growth" Journal of International Economics Vol 45, Issue 1 p 1.

Bronfman, M.K. (2006) "Fair and Equitable Treatment: An Evolving Standard" Max Planck Yearbook of United Nations Law, Vol. 10, p611.

Dolzer, R.(2014) "Fair and equitable Treatment: Today's Contours", Santa Clara Journal of International Law, Vol. 12, Issue 1 .( Symposium on the Law and Politics of Foreign Investment). pp 10-11.

Herbert, S. F. (2016) “A Multi-Jurisdictional Review on Dispute Resolution in Africa Legal Guide”, Second Edition · p 15

Kanyangoga, J.B.(2014) "The MFN clause in the EAC-EU EPA negotiations: State of play and related implications" Bridges Africa Vol. 3, Issue 2, pp. 14 15.

Mahembe, E. \& Odhiambo, N. O. (2013). "The Dynamics of Foreign Direct Investment in Southern African Development Community Countries: Experiences from Five Middle-Income Economies" Problems and Perspectives in Management, Vol 11, Issue 4. pp 35-43.

Schlemmer,C.E.(2016) “An Overview of South Africa's Bilateral Investments Treaties and Investment Policy" ICSID Review Vol. 31 No.1Published Advance Access. pp. 163-193

Sharp, M. (2015) "Policy Framework for Foreign Direct Investment and Promotion in South Africa: Operations, Effectiveness and Sustainability: South African Institute of International Affairs, Occasional Paper 215, Economic Diplomacy Programme.p8.

South Africa-Foreign Investment-Attitude Toward FDIs, South Africa-Openness to and Restrictions on FDIs.
Ewulukwa,U. (2014) “Africa and the System of InvestorState Dispute Settlement: To Reject or Not to Reject" Available at Attorney General's Department, Ghana, Africa International Legal Awareness http://www.biogaila.com./2014/10/12.

Xavier, C. (2015).“International Investments Agreements and Africa's Structural Transformation: A perspective from South Africa" South Centre Investment Policy Brief No 4. p1-7.

http://oecd.org.Investment https://books.google.com.gh $(23 / 02 / 17)$

http://exportgov/usoffices. (08/11/2016)

http://.www.sars.gov.og (15/12/2016)

http://kpmg.com (13/12/2016)

http://www.labour.gov.za (15/12/16)

http://www.gipcghana.com (13/03/17)

http://www.deloite.com.za. (01/03/17)

http://sars.gov.za/clientSegments/CustomsExcise/Pages/T ariff.aspx. (13/03/17) 